Pena Justisia: Media Komunikasi dan Kajian Hukum
Vol. 17 No. 1, 2017, 20-27
Artikel Gagasan Konseptual

\title{
Hukum dan Kebijakan Ekonomi: Studi Kasus One China Policy
}

\author{
Lynda Asiana
}

Fakultas Hukum Jenderal Soedirman, Indonesia

Artikel Diterima:

6 April 2017

Artikel Disetujui:

29 Mei 2017

Artikel Diterbitkan:

10 Juni 2017

Korespondensi Penulis:

lyndaasiana@yahoo.co.id

\begin{abstract}
Taiwan is a country with a capitalist ideology and as one of the centers of world economic entities. Nevertheless, Taiwan's status as a country is still considered unclear. Countries in the world are no exception UN participating countries do not recognize Taiwan as a state entity. In the midst of the question of the existence of Taiwan as a sovereign state, the WTO has officially accepted as its members. This article examines what makes the WTO's basis for accepting Taiwan as a WTO member and whether Taiwan's acceptance as a WTO member is not inconsistent with One China Policy. Based on the results of the study, Taiwan membership in WTO Organization is based that Taiwan as one of the centers of the world economic entity has special autonomy so that it can conduct foreign relations. Taiwan's presence in WTO membership does not conflict with One China Policy because the WTO base makes Taiwan its member is not based on a country but based on economic entities and special autonomy.
\end{abstract}

Keywords: WTO, One China Policy, Economic Policy

Abstrak

Taiwan merupakan suatu negara yang berideologi kapitalis dan sebagai salah satu pusat entitas ekonomi dunia. Namun demikian, status taiwan sebagai negara dinilai masih belum jelas. Negara-negara di dunia tidak terkecuali negara-negara peserta PBB tidak mengakui Taiwan sebagai entitas negara. Ditengah-tengah persoalan tentang keberadaan Taiwan sebagai negara yang berdaulat, WTO secara resmi telah menerima sebagai anggotanya. Artikel ini mengkaji mengenai apakah yang menjadikan dasar WTO untuk menerima Taiwan sebagai anggota WTO dan apakah penerimaan Taiwan sebagai anggota WTO tidak bertentangan dengan One China Policy. Berdasarkan hasil kajian, Keanggotaan Taiwan dalam Organisasi WTO didasarkan bahwa Taiwan sebagai salah satu pusat entitas ekonomi dunia memiliki otonomi khusus sehingga dapat melakukan hubungan luar negeri. Keberadaan Taiwan dalam keanggotaan WTO tidak bertentangan dengan One China Policy karena dasar WTO menjadikan Taiwan sebagai anggotanya adalah tidak didasarkan pada sebuah negara, tetapi didasarkan pada entitas ekonomi dan otonomi khusus.

Kata Kunci: WTO, One China Policy, Kebijakan Ekonomi 


\section{PENDAHULUAN}

Pada masa lalu perubahan sosial (social change) yang cepat akibat proses modernisasi dirasakan sebagai sesuatu yang potensial dapat menimbulkan keresahan dan ketegangan sosial (social unrest and social tension). Perubahan sistim nilai dengan cepat menuntut adanya norma-norma kehidupan sosial baru yang menyibukkan badan legislatif, lembaga-lembaga penyelesaian sengketa (in dan out court) dan usaha-usaha untuk sosialisasi hukum. ${ }^{1}$

Keadaan demikian ini menuntut adanya hukum yang terbuka terhadap perkembangan dan dinamika masyarakat di era globalisasi. Apa yang disebut modernisasi dan globalisasi tidak bersifat fakultatif, tetapi merupakan fenomena yang harus dihadapi (change is not optional) dan tidak dapat dihindari. Keduanya merupakan sesuatu yang alamiah yang timbul serta-merta akibat kompleksitas dan heterogenitas hubungan antar manusia sebagai masalah sosial sebagai akibat penemuan alat-alat teknologi modern.

Semakin meningkatnya proses modernisasi akibat ditemukannya alat-alat komunikasi modern, alat komunikasi dan teknologi informatika modern, isu modernisasi menjadi mendunia dan memunculkan fenomena baru berupa globalisasi yang menuntut perubahan struktur hubungan hukum (legal structure), substansi-substansi baru pengaturan hukum (legal substance) dan budaya hukum(legal culture) yang seringkali sama sekali baru. Tanpa adanya perubahan sistim hukum tersebut akan timbul bahaya-bahaya terhadap ketentraman hidup (peacefull life) dalam berbagai kehidupan sosial, semua akan menjadi tidak pasti dan tidak tertib serta rasa tidak terlindungi. ${ }^{2}$

Menghadapi globalisasi yang semakin deras memasuki sendi-sendi kehidupan bermasyarakat, berbangsa dan bernegara, Anthony Giddens memikirkan "jalan ketiga” sebagai pilihan ketiga

Muladi, 1997, Hak Asasi Manusia, Politik dan Sistem Peradilan Pidana, Semarang: Badan Penerbit Universitas Diponegoro, hlm. 57

Ibid, hlm. 57

3 Anthony Giddens, 1999, Jalan Ketiga: Pembaharuan Demokrasi Sosial, Jakarta: Gramedia Pustaka Utama, hlm. ix antara sosialisme dan kapitalisme, atau antara intervensi negara dan pasar bebas. ${ }^{3}$ Dunia pada penghujung abad ke-20 ini dicirikan oleh "manufactured uncertainty", yakni masa yang diliputi oleh ketidakpastian. Situasi ini tidak ditimbulkan oleh alam, tetapi oleh manusia sendiri berkat teknologi yang diciptakannya. ${ }^{5}$ Hal ini berarti bahwa manufactured uncertainty akhirnya mengarah kepada "high concequence risk". 6 Memang dalam hidup ini manusia harus mengambil banyak pilihan yang mengandung banyak resiko, tetapi resiko yang harus diambil manusia adalah jenis resiko yang mempunyai konsekuensi yang amat jauh. Krisis ekonomi yang menimpa Asia pada tahun 1997 adalah contoh lain yang telah kita alami. Hal ini dikemukakan tidak untuk menyangkal bahwa manusia telah berhasil menghasilkan kehidupan modern yang memuat kepastian-kepastian (ia memakai istilah ontological security). ${ }^{7}$

Dalam dunia bisnis, globalisasi tidak hanya sekedar berdagang dibeberapa negara di dunia, tetapi berdagang diseluruh dunia dengan cara baru yang menjaga keseimbangan antara kualitas global, hasil produksi dengan kebutuhan khas yang bersifat lokal dari konsumen. Cara baru ini dipengaruhi oleh adanya saling ketergantungan antara bangsa yang semakin meningkat (dunia = the big village), berlakunya standar-standar dan kualitas baku internasional, melemahnya ikatanikatan etnosentrik yang sempit, peningkatan peran swasta dalam bentuk korporasi internasional ( $M N E^{\prime} S$ ), melemahnya ikatan-ikatan nasional di bidang ekonomi, peranan informasi sebagai kekuatan meningkat, munculnya kebutuhan akar, manusia-manusia brilian tanpa melihat kebangsaannya dan sebagainya. ${ }^{8}$

Perbedaan sistem hukum antar negara tidak menjadi halangan untuk menjalin hubungan antar negara. Sebab setiap negara sepakat untuk

4 Anthony Giddens, 1994, Beyond Life and Right, Cambridge: Polity Press, hlm. 4

Anhony Giddens, 1999, Op.cit, hlm. ix

Ibid.

Anthony Giddens, 1999, hlm. xi

Muladi, Op.cit, hlm. 48 
mengikatkan diri serta tunduk dalam hukum yang diakui bersama yakni hukum internasional. Hukum Internasional dapat didefinisikan sebagai keseluruhan hukum yang untuk sebagian besar terdiri dari prinsip-prinsip dan kaidah-kaidah perilaku yang terhadapnya negara-negara merasa dirinya terikat untuk menaati sehingga hukum internasional secara umum ditaati oleh negara dalam hubungan-hubungan antar negara satu sama lain. Hukum internasional menjadi suatu instrumen untuk mengatur ketertiban serta kesejahteraan antar negara dalam kaitannya melakukan hubungan baik untuk menjalin kerjasama maupun hubungan untuk saling membantu antar negara. ${ }^{9}$

Pengakuan merupakan pernyataan dari suatu negara yang mengakui suatu negara lain sebagai subjek hukum internasional. Pengakuan berarti bahwa selanjutnya antara negara yang mengakui dan negara yang diakui terdapat hubungan sederajat dan dapat mengadakan segala macam hubungan kerja sama satu sama lain untuk mencapai tujuan nasional masing-masing yang diatur oleh ketentuan-ketentuan Hukum Internasional. Pengakuan juga berarti menerima suatu negara baru ke dalam masyarakat Internasional. ${ }^{10}$

Lahirnya negara baru dapat melalui berbagai macam cara seperti melepaskan diri dari penjajahnya bagi bekas wilayah-wilayah jajahan, pemisahan diri sebagian wilayah suatu negara dan berdiri sendiri sebagai sebuah negara merdeka, atau pecahnya sebuah negara menjadi beberapa negara menjadi sebuah negara yang baru sama sekali. ${ }^{11}$ Kelahiran negara baru tersebut dalam masyarakat internasional akan menimbulkan reaksi negara-negara lain yang dimanifestasikan dalam pernyataan sikap menerima atau mengakui kehadiran negara tersebut atau mungkin sebagian lagi ada negara-negara yang menolak atau tidak mau memberikan pengakuannya atas kehadiran negara baru tersebut. ${ }^{12}$

\footnotetext{
9 J.G. Starke, Pengantar Hukum Internasional Edisi Kesepuluh, Sinar Grafika: Jakarta, 2001, hlm.3

10 Boer Mauna, Hukum Internasional Pengertian Peranan dan Fungsi dalam Era Dinamika
}

Seringkali terjadi suatu negara baru memiliki banyak kekurangan di seperti misalnya pemerintahannya yang masih lemah, batas-batas wilayahnya masih samar-samar, ataupun masih terjadi huru-hara atau pemberontakan-pemberontakan lokal di dalam wilayah negara baru tersebut, dan berbagai masalah intern lainnya. Keadaan tersebut dapat menimbulkan sikap raguragu, apakah terhadap negara semacam itu sudah pantas diberikan pengakuan ataukah tidak. Pemberian pengakuan sering kali dilakukan berdasarkan pertimbangan politik dari negara atau pihak yang memberi pengakuan. ${ }^{13}$

Taiwan merupakan suatu negara yang berideologi kapitalis dan sebagai salah satu pusat entitas ekonomi dunia. Namun demikian, status taiwan sebagai negara dinilai masih belum jelas. Sebagian terbesar dari negara-negara di dunia tidak terkecuali negara-negara peserta PBB tidak mengakui Taiwan sebagai entitas negara. Akibatnya adalah mereka tidak mengadakan hubungan diplomatik dengan Taiwan. Namun demikian, ditengah-tengah persoalan tentang keberadaan Taiwan sebagai negara yang berdaulat, WTO secara resmi telah menerima sebagai anggotanya. Sebagai anggota, Taiwan mempunyai hak dan kewajiban sebagaimana yang dimiliki anggotaanggota WTO lain. Dilain pihak, RRC menganggap bahwa Taiwan merupakan sebuah provinsi bagian Fujian yang memberontak, dan oleh karena itu Taiwan masih berada dibawah kekuasaan dan merupakan bagian wilayah RRC. Sementara dipihak Taiwan, Taiwan menyebut dirinya sebagai sebuah negara yang berdaulat. Hal ini berarti bahwa Taiwan berkedudukan sebagaimana negara-negara anggota WTO lainnya, walau bertentangan dengan kebijakan One China Policy, yakni hanya ada satu negara berentitas China, yaitu RRC.

Berdasarkan latar belakang masalah di atas, pokok permasalahan yang dikaji dalam tulisan ini yakni apakah yang menjadikan dasar

11 I Wayan Parthiana, Pengantar Hukum Internasional, Penerbit Mandar Maju : Bandung, 2003, hlm. 398.

12 Ibid, hlm. 339

13 Ibid. 
WTO untuk menerima Taiwan sebagai anggota WTO dan apakah penerimaan Taiwan sebagai anggota WTO tidak bertentangan dengan One China Policy.

\section{PEMBAHASAN}

Pengakuan terhadap suatu negara dapat dilihat dari sejauh mana negara tersebut memiliki hubungan bilateral dengan negara lainnya untuk menjalin kerjasama di bidang sosial, politik, ekonomi dan pertahanan. Tanpa adanya hubungan bilateral, suatu bangsa dapat dikatakan tidak memiliki kedaulatan atau pengakuan internasional. Berkaitan dengan hal tersebut setiap negara di dunia pasti akan menjalin hubungan bilateral dengan negara lainnya yang akan saling mengutungkan satu sama lain. Hubungan bilateral di antara negara - negara tersebut sering terkendala oleh masalah klaim kedaulatan dari negara yang satu dengan yang lainnya seiring perkembangan waktu. Salah satu di antara contoh tersebut adalah hubungan antara People's Republic of China (China) dan Republic of China (Taiwan). ${ }^{14}$

Taiwan merupakan salah satu negara yang memiliki pengaruh kuat di kawasan Asia. Secara resmi memang banyak negara yang belum mengakui Taiwan sebagai suatu negara berdaulat karena China sendiri selalu melaksanakan One China Policy kepada negara-negara lain di dunia. Republik Rakyat China masih menganggap bahwa Taiwan merupakan sebuah provinsi bagian Fujian yang memberontak, sedangkan Taiwan menyebut dirinya sebagai sebuah negara sendiri yang beraliran Koumintang atau Nasionalis dan tidak ingin disamakan dengan China.

Belum diakuinya Taiwan sebagai sebuah negara oleh sebagian besar negara lain di dunia merupakan kendala besar bagi Taiwan untuk menjalin hubungan diplomatik dan hubungan kerjasama yang lebih luas. Bahkan Perserikatan Bangsa-Bangsa (PBB) sebagai suatu Organisasi Internasional yang menaungi seluruh negara tidak mengakui Taiwan sebagai anggotanya. Hal ini membuat banyak negara di berbagai belahan dunia hanya melakukan hubungan kerjasama dalam perdagangan, perekonomian, dan ketenagakerjaan dengan Taiwan termasuk Indonesia. Indonesia telah memiliki hubungan kerjasama dengan Taiwan sejak tahun 1960.

Indonesia selalu berpegang teguh dengan prinsip One China Policy atau kebijakan satu China, artinya secara de jure Indonesia hanya menjalin hubungan diplomatik dengan Republik Rakyat China (RRC). Indonesia tidak mengakui Taiwan sebagai sebuah negara yang berdaulat dan merdeka dari China tetapi bukan berarti antara Indonesia dan Taiwan tidak menjalin hubungan kerjasama. Hubungan antara Indonesia dengan Taiwan hanya sebatas hubungan kerjasama perdagangan dan ekonomi. Hal ini dikarenakan Indonesia ingin tetap menjalin hubungan yang baik dengan pemerintah China baik hubungan diplomatik maupun hubungan kerjasama ekonomi. ${ }^{15}$

Sejak Oktober 1949, Taiwan terus berusaha memisahkan diri dari China. Usaha yang dilakukan oleh Taiwan yaitu Pragmatic Diplomacy yang dijalankan Taiwan memperlihatkan keinginan untuk melepaskan diri dari China. Taiwan giat membuka hubungan diplomatik dengan berbagai negara di Afrika ataupun memberi bantuan dana kepada PBB yang diartikan oleh China sebagai keinginan untuk mendirikan negara terpisah. Taiwan hingga kini masih berkutat mencari pengakuan internasional. Status politik negara kecil di Laut China Timur itu masih simpang siur.

Tahun 1949 pemerintahan Partai Rakyat Kuomintang kalah dalam perang saudara melawan Partai Komunis di China daratan, setelah itu mereka melarikan diri ke pulau Taiwan dan mendirikan negara. Sejak perang saudara di China sekitar tahun 1940, China menganggap Taiwan bagian dari wilayahnya. China menolak hubungan diplomatik dengan negara manapun yang secara resmi mengakui Taiwan. ${ }^{16}$

16 BBC News, Hubungan China-Taiwan, http://www.bbc.co.uk /indonesian/news/story/2007 /01/070108_chinachenshuibian. shtml, diakses tanggal 12 Desember 2017. 
Sebelum Presiden Taiwan Ma Ying-jeou menjabat, kedua pihak berupaya menarik sekutu dengan menawarkan dana kepada negara-negara lain untuk beralih aliansi. Sampai dengan beberapa tahun yang lalu, China dan Taiwan menyetujui perjanjian untuk menghentikan praktek tersebut. Sejak itu keduanya berusaha meredakan ketegangan dan membangun kepercayaan. China berusaha memenangkan simpati masyarakat Taiwan lewat perjanjian-perjanjian yang meningkatkan ekonomi pulau itu. Pada saat perang anti Jepang di China, Partai Kuomintang China dan Partai Komunis China telah menggalang front penyatuan nasional anti Jepang untuk melawan agresi imperialisme Jepang. Setelah kemenangan perang anti Jepang, Kuomintang yang dipimpin Chiang Kai-sek dengan mengandalkan dukungan Amerika, melancarkan perang saudara di seluruh negeri. ${ }^{17}$

Sejak saat itu hubungan antara Taiwan dengan pemerintahan di China daratan kembali membeku. Kedua negara juga menolak memberikan pengakuan resmi terhadap satu sama lain, sebaliknya dengan Undang-undang Anti Separasi yang disahkan pada tahun 2005 lalu, China mengancam akan menyerang Taiwan jika negara itu mendeklarasikan kemerdekaan secara resmi. Pada tahun 1971 Taiwan kehilangan keanggotaan di Perserikatan Bangsa-bangsa menyusul keberatan China.

Taiwan mencoba kembali untuk menjadi anggota $\mathrm{PBB}$, tetapi selalu gagal karena dihalangi oleh China. China berusaha mengedepankan One China Policy yang dipromosikan oleh pemerintah Republik Rakyat China disamping melakukan tekanan ekonomi dan diplomatik kepada Taiwan. Sebagian besar negara di dunia mengubah arah diplomatiknya ke pemerintahan Republik Rakyat China sekitar tahun 1970 dan hingga tahun 2008 Republik China di Taiwan hanya diakui oleh dua puluh tiga negara saja.

17 Fx Sutopo, 2000, Sejarah Singkat China. Jakarta: Gramedia, hlm. 43
Dilihat dari syarat umum adanya suatu negara yang tercatum dalam Konvensi Montevideo 1933, Taiwan telah memenuhi tiga unsur dasar untuk menjadi negara. Syarat tersebut adalah wilayah, penduduk dan pemerintahan, dan dalam hal pengakuan secara de jure tiga unsur tersebut belum cukup untuk menentukan status Taiwan sebagai negara berdaulat.

Unsur terpenting dalam politik internasional adalah pengakuan dari negara lain. Pengakuan negara lain inilah yang menentukan eksistensinya, bukan sekedar de facto ataupun proses politik internalnya. Berdasarkan Resolusi PBB A/RES/2758 sebagai hasil pemungutan suara di Majelis Umum PBB pada 25 Oktober 1971, telah disepakati bahwa kursi keanggotaan Republic of China dialihkan kepada pemerintahan People Republic of China, akibatnya pemerintahan Republik of China sudah tidak diakui lagi di dalam dunia internasional. ${ }^{18}$

Sejak tanggal 1 Januari 2002 Taiwan masuk menjadi anggota WTO. WTO tercatat memiliki anggota sejumlah 162 negara pada bulan November tahun 2015 termasuk China dan Taiwan. WTO memberikan hak kepada negara-negara anggotanya untuk melakukan perdagangan antar negara anggotanya secara bebas guna menciptakan dunia yang stabil melalui sistem multilateral berdasarkan kepada negara yang menyetujui. Secara teori, hukum nasional negara yang menjadi anggota WTO tidak dapat berlawanan dengan aturan WTO. Ketika meratifikasi perjanjian WTO, negara akan mengimplementasikan aturan-aturan yang terdapat dalam WTO untuk diterapkan dalam hukum nasionalnya.

Keanggotaan Taiwan dalam WTO bukan berdasarkan status kenegaraan melainkan berdasarkan otonomi khusus yang dimilikinya. Prinsip One China Policy menyatakan bahwa Republik Rakyat China merupakan satu-satunya China, sedangkan Republik China atau Taiwan hanya memiliki otonomi khusus di bawah kekuasaan China.

18 Grace Lestariana Wonoadi, Menelisik Kedaulatan Taiwan, http://hi.umy.ac.id/menelisik-kedaulatan-taiwan/ , diakses tanggal 12 Desember 2017 
Tentunya hal tersebut membuat Taiwan dapat menjadi anggota WTO karena termasuk ke dalam definisi sebagai pemilik otonomi khusus yang dapat melakukan hubungan luar negeri. ${ }^{19}$

China dan Taiwan sama-sama ingin bergabung dengan forum Asian-Pasific Economic Cooperation (APEC) dan GATT. Amerika Serikat dan negara-negara lainnya mendukung bergabungnya kedua negara tersebut. Keduanya saat ini merupakan anggota dari APEC dan GATT (WTO) walaupun Taiwan masih harus menggunakan nama China Taipei. Sehubungan dengan keanggotaan pada GATT, permohonan baik oleh China dan Taiwan saat ini berada di bawah pertimbangan GATT. Permohonan Taiwan menggunakan nama Custom Territory of Taiwan, Penghu, Kinmen, and Matsu sehingga China tidak menentang keanggotaan Taiwan di GATT, walaupun China bersikeras bahwa Taiwan harus menggunakan nama China Taipei.

Sumaryo Suryokusumo berpendapat bahwa penerimaan negara atau subjek hukum internasional lainnya sebagai anggota atau dengan status tertentu oleh suatu organisasi internasional secara tersirat mengandung pengakuan organisasi tersebut terhadap negara maupun subjek hukum internasional. Pengakuan secara tersirat tersebut tidak hanya terjadi pada negara tetapi juga pada kesatuan-kesatuan lainnya yang dapat dianggap sebagai subjek hukum internasional seperti Monako, Vatikan, Swiss, dan lain-lain walaupun keberadaan mereka di PBB bukan sebagai anggota. ${ }^{20}$ Secara tersirat dapat diartikan bahwa Taiwan telah mendapatkan pengakuan kedaulatan dari WTO, tetapi pengakuan tersebut tidak semata-mata menimbulkan penafsiran bahwa Taiwan telah mendapatkan pengakuan atas eksistensinya sebagai negara maupun sebagai subjek hukum internasional.

19 Steve Charnovitz, Taiwan's WTO Membership and Its International Implications, hlm. 421, http://scholarship .law.gwu.edu/cgi/viewcontent.cgi?article=1436\&context =faculty_publications, diakses tanggal 12 Desember 2017

20 Sumaryo Suryokusum, 1997, Studi Kasus Hukum Organisasi Internasional, Bandung: Alumni, hlm. 68.
Taiwan saat ini dikenal secara luas sebagai sebuah entitas kelautan dan sebuah territorial adat yang terpisah dalam persetujuan kelautan multilateral dan juga dalam Organisasi Perdagangan Internasional. Identitas baru Taiwan digunakan untuk membentuk basis yang legal bagi Taiwan untuk mengakses Pengadilan Intenasional dalam Hukum Kelautan dan WTO.

Pembukaan hubungan diplomatik dan pembukaan perwakilan tetap dalam Konvensi Wina 1961 merupakan dua hal yang berbeda. Suatu negara dapat membuka hubungan diplomatik tanpa diikuti pembukaan perwakilan tetap. Data yang diperoleh dari hasil penelitian mengenai negara mana saja yang membuka hubungan diplomatik dengan Taiwan menunjukkan bahwa 13 dari 23 negara yang mengakui kedaulatan Taiwan telah mendirikan kantor kedutaan besar di Taipei, sedangkan 10 negara lainnya hanya menempatkan kantor konsulat dan konsulat jenderal saja. Negara yang mendirikan kedutaan besar di Taiwan diantaranya adalah Vatikan, Belize, Afrika Tengah, Dominika, El Salvador, Guatemela, Guinea-Bissau, Haiti, Honduras, Nikaragua, Panama dan Paraguay. ${ }^{21}$ Dilihat dari jumlah negara yang menjalin hubungan diplomatik secara resmi dengan Taiwan, maka belum cukup untuk membuktikan eksistensi Taiwan sebagai negara yang berdaulat meupun sebagai subjek hukum internasional.

Yurisdiksi Mahkamah Internasional didasarkan pada persetujuan para pihak. Suatu negara dapat terikat dengan yurisdiksi Mahkamah Internasional melalui persetujuan khusus, perjanjian, dan konvensi, atau dengan pengakuan yurisdiksi wajib Pengadilan. Dasar hukum yurisdiksi Mahkamah Internasional terkandung dalam Pasal 36 Statuta Mahkamah Internasional. Pasal 36 ayat 1 Statuta Mahkamah Internasional menjelaskan

21 Hungdah Chiu, The international legal status of the Republic of China, hlm. 26. http://digitalcommons.law.umaryland .edu/cgi/viewcontent.cgi?article=1111\&context=mscas, diakses tanggal 12 Desember 2017. 
bahwa yurisdiksi Mahkamah Internasional meliputi semua perkara yang diajukan pihak-pihak yang bersengketa kepadanya dan semua hal, terutama yang terdapat dalam Piagam PBB atau dalam perjanjian-perjanjian dan konvensi-konvensi yang berlaku. Dapat dikatakan bahwa meskipun Taiwan bukan merupakan negara yang menjadi bagian dari Statuta Mahkamah Internasional tetapi Taiwan dapat menerima yurisdiksi Mahkamah Internasonal dengan dasar perjanjian atau konvensi yang mengharuskan penyelesaian sengketa yang timbul dari perjanjian-perjanjian tersebut untuk tunduk kepada yurisdiksi Mahkamah Internasional.

Dasar hukum yang paling tepat bagi Taiwan untuk mendapatkan kedudukan dihadapan Mahkamah Internasional adalah Pasal 35 ayat 2 Statuta Mahkamah Internasional dan Resolusi 9 Dewan Keamanan. Mahkamah Internasional tidak pernah menolak pernyataan yurisdiksi suatu Negara. Apabila Taiwan menaati ketentuan yang diatur dalam Resolusi tersebut, Mahkamah Internasional dapat mempertimbangkan pengakuan peradilan di seluruh dunia terhadap Taiwan sebagai negara yang memiliki kedudukan dihadapan pengadilan. ${ }^{22}$ Praktek dalam hukum internasional, selama ini Taiwan belum pernah berperkara di Mahkamah Internasional karena statusnya yang secara diplomatik belum kuat, sehingga eksistensinya sebagai subjek hukum internasional masih di bawah kedaulatan China.

Jika dinilai berdasarkan prinsip hukum pengakuan internasional, Taiwan seharusnya diakui sebagai sebuah negara oleh semua negara yang ada. Karena di bawah hukum internasional, memberikan pengakuan merupakan sebuah tindakan politik. Amerika Serikat tidak akan mengakui ulang Taiwan karena kepentingan politik internasional dalam mempertahankan hubungan persahabatan dengan China. China merupakan anggota permanen dalam United Nations Security Council atau Dewan Keamanan PBB. Mengakui

22 Pasha L. Heish , An Unrecognized State in Foreigen and International Courts: The case of Republic of China on Taiwan, hlm. 798, http://ink.library.smu.edu.sg/cgi/
Taiwan secara formal berarti menempatkan hubungannya dengan China dalam resiko.

\section{PENUTUP}

Keanggotaan Taiwan dalam Organisasi WTO didasarkan bahwa Taiwan sebagai salah satu pusat entitas ekonomi dunia memiliki otonomi khusus sehingga dapat melakukan hubungan luar negeri. Keberadaan Taiwan dalam keanggotaan WTO tidak bertentangan dengan One China Policy karena dasar WTO menjadikan Taiwan sebagai anggotanya adalah tidak didasarkan pada sebuah negara, tetapi didasarkan pada entitas ekonomi dan otonomi khusus. Namun demikian, China bersikeras bahwa Taiwan harus menggunakan China Teipei sebagai bukti bahwa hanya ada satu China sebagaimana yang dikehendaki oleh One China Policy.

\section{DAFTAR PUSTAKA}

AK, Syahmin. 1984. Hukum Diplomatik Suatu Pengantar. Bandung: CV Armico;

Anwar, Chairul. 1989. Hukum Internasional: Pengantar Hukum Bangsa-Bangsa, Jakarta: Djambatan;

BBC News, Hubungan China-Taiwan, dikutip dari:http://www.bbc.co.uk/indonesia/ news/story/2007/01/070108_chinach enshuibian. shtml, diakses tanggal 12 Desember 2017.

Giddens, Anthony. 1994. Beyond Life and Right. Cambridge: Polity Press. Anthony Giddens. 1999.Jalan Ketiga: Pembaharuan Demokrasi Sosial.Jakarta: Gramedia Pustaka Utama;

1999.Jalan Ketiga: Pembaharuan Demokrasi Sosial.Jakarta: Gramedia Pustaka Utama;

Grace Lestariana Wonoadi, Menelisik Kedaulatan Taiwan, dikutip dari: http://hi.umy.ac.id/ menelisik-kedaulatan-taiwan/, Diakses pada 12 Desember 2017

viewcontent.cgi article $=1526 \&$ context $=$ sol_research , diakses tanggal 12 Desember 2017. 
27 Pena Justisia: Media Komunikasi dan Kajian Hukum Vol. 17, No. 1, 2017

Hungdah Chiu, The international legal status of the Republic of China, hlm. 26. http://digital commons.law.umaryland.edu/cgi/viewcon tent.cgi?article $=1111 \&$ context $=$ mscas, diakses tanggal 12 Desember 2017.

Mauna, Boer, 2005, Hukum Internasional Pengertian Peranan dan Fungsi dalam Era Dinamika Global, PT Alumni, Bandung

Muladi. 1997.Hak Asasi Manusia. Politik dan Sistem Peradilan Pidana.Semarang: Badan Penerbit Universitas Diponegoro;

Parthiana, I Wayan, 2003, Pengantar Hukum Internasional, Penerbit Mandar Maju, Bandung

Pasha L. Heish , An Unrecognized State in Foreigen and International Courts: The case of Republic of China on Taiwan, dikuti dari laman, http://ink.library.smu.edu.sg/cgi/ viewcontent. cgi? article $=1526 \&$ context $=$ sol_research, diakses tanggal 12 Desember 2017.

Starke, J.G. 2001. Pengantar Hukum Internasional Edisi Kesepuluh. Jakarta: Sinar Grafika

Steve Charnovitz, Taiwan's WTO Membership and Its International Implications, dikutip dari: http://scholarship.law.gwu.edu/cgi/viewc on tent.cgi?article $=1436 \&$ context=faculty _publications, diakses tanggal 12 Desember 2017

Sutopo, F.X. 2000. Sejarah Singkat China. Jakarta: Gramedia; 